\title{
CHRISTIAN JÜRGENSEN THOMSENS MUSEUM - EN GULDALDERVISION
}

\author{
Jørgen Jensen
}

I aret 1807 blev grunden lagt til det, der skulle blive til Nationalmuseet i København. Det skete ved oprettelsen af den såkaldte Kongelige Kommission til Oldsagers Opbevaring, som på loftet over Trinitatis kirke bag ved Rundetairn indsamlede kulturhistoriske genstande ikke blot fra oldtiden men også fra middelalderen og senere tider. Grundlaggelsen af museet skete fa maneder for englandernes bombardement af København i september 1807, og historien indhentede salledes hurtigt den lille nye samling, som var et sidste produkt af oplysningstidens tonkning. Med Danmarks inddragelse i Napoleonskrigene sluttede en epoke, og en ny begyndte, der snart skulle fore til nationale katastrofer som både statsbankerotten i 1813 og tabet af Norge i 1814. Men i et videre perspektiv også til en kulturel blomstring af dimensioner, som ikke tidligere var set $i$ Danmark.

Grundlæggelsen af Oldsagskommissionens samlinger i København var et sidste produkt af 1700-tallets kulturpolitiske program. Det ser man af den "profetiske vision", som en af mændene bag kommissionen, litteraten Rasmus Nyerup i 1807 publicerede om et kommende Nationalmuseum. ${ }^{1}$ Her skildrede han, hvordan den danske hovedstad 30 år frem i tiden ville være smykket med tre herlige bygninger: Et Pantheon for berømte danske og norske, som skulle ligge, hvor Marmorkirken ligger nu - et kongeligt skuespilhus, hvor man kun spillede danske stykker - og et kongeslot, et Christiansborg, der rummede et Nationalmuseum. I sin vision beskriver Nyerup, hvordan museet er indrettet: "saaledes ongefær" som Alexandre Lenoirs Musée des Monuments Français i
Paris. Og han slutter besøget i det endnu imaginære danske Nationalmuseum med at sige: "Hvad jeg følte ved at gennemvandre dette Museum, kan jeg umulig beskrive. Hjertet banker af vemodig Glæde, naar Fortiden saaledes oprulles for vore $\varnothing$ jne". Tredive år senere stod slottet der, og det rummede $\mathrm{i}$ hvert fald begyndelsen til et Nationalmuseum.

Det museum, som Rasmus Nyerup så som forbillede for sit Nationalmuseum, var Alexandre Lenoirs museum i Paris, som for offentligheden havde gjort tilgængelig de samlinger af kunstværker fra middelalderlige kirker og klostre, der var blevet plyndret ved den franske revolution. ${ }^{2}$ Tanken om det offentlige museum som et opdragelsessted for hele folket var noget, der lå dybt forankret i Oplysningstidens forestillings- 
verden. Den var kommet til udtryk, da British Museum i 1759 åbnedes for offentligheden, ${ }^{3}$ og da landgreve Friedrich II af Hessen-Kassel ti år senere begyndte byggeriet af "Friedericianum" i Kassel, der skulle blive det første museum nogensinde bygget som sådant i Europa. ${ }^{4}$ Men især var tanken kommet til udtryk efter den franske revolution, da Louvre i 1793 åbnedes under navnet Museum Français, og da Lenoir samme år slog dørene op til sit museum.

Le Musée des Monuments Français opstod på en klostergrund i Paris i rue des Petits Augustins. Her skabte Lenoir et offentligt museum, som i kronologisk rækkefølge skulle vise kunstens udvikling fra middelalderen frem til det 17 . århundrede. Hvert af udstillingsrummene var udstyret således, at det gengav atmosfæren fra det pågældende århundrede. I virkeligheden var det en forløber for det interieurprincip, der senere i århundredet skulle blive så almindeligt. Til museet knyttede sig også en romantisk park, et slags elysium, med gravminder for berømte franskmænd. Museet blev således til et stemningsfyldt konglomerat af middelalderlige bygninger og grave, et sted for følelsesfuld fordybelse $i$ fortiden. Fra dette museum udgik en stærk inspiration til de kulturhistoriske museer, der skulle udvikle sig i det følgende århundrede overalt i Europa. Ikke blot i København men også $\mathrm{i}$ en lang række andre europæiske byer.

Museet i Louvre, der var åbnet samtidig med Lenoirs museum, fik en lige så dybtgående betydning for udviklingen af de europæiske kunstmuseer. I Louvre anbragte man nemlig de kunstskatte, Napoleon inddrog overalt, hvor han kom frem i Europa og Nordafrika. ${ }^{5}$ Louvre blev nu det største museum i Europa efter Museo Pio
Clementino i Vatikanet. I 1804 fik museet navneforandring til Musée Napoleon, og det blev her, man for første gang i stor stil arrangerede kunstværkerne i skoler efter et historisk ordningsprincip. $\mathrm{Nu}$ kunne det europæiske borgerskab møde den ægyptiske kunst, her kunne man se senmiddelalderens og den tidlige renæssances kunst både fra Italien og landene nord for Alperne. Man kunne sammenligne forskellige landes kunstfrembringelser, og man kunne betragte kunsten i hele dens udviklingsforløb.

Også denne kunsthistoriske betragtningsmåde udsprang af 1700-tallets klassicisme. Oplysningstidens fascination af den klassiske oldtids kunst havde sit klare ideologiske præg: Den græske kunst fra antikken, mente man, var opstået under et frit, demokratisk styre. Netop derfor var den så fuldendt og forbilledlig. I antikkens Grækenland havde kunsten, lige som en levende organisme, haft sin egen indre udvikling, der var gået igennem opvækst, blomstring og forfald. Uden en historisk erkendelse heraf var al kunstnerisk produktion utænkelig. Det var det idealistiske syn, Winckelmann havde fremlagt i sin "Geschichte der Kunst des Alterthums" fra 1764, og med det var kunsthistorien vokset frem som en disciplin.

I uløselig forbindelse med den politiske tænkning blev denne historiske betragtningsmåde $\mathrm{i}$ begyndelsen af 1800-tallet til en del af det alment-kulturelle mønster: Historien blev - lige som troen på, at man levede $\mathrm{i}$ en fremskridtets tidsalder - til en livsholdning. Ja, med tiden til en dyb besættelse, der gennemtrængte alle åndslivets sfærer. Man begyndte at betragte historien fra de ældste tider til nutiden som et stort, sammenhængende udviklingsforløb - 
og netop det gav baggrunden for ordningen af de kunst- og kulturhistoriske samlinger efter geografiske og kronologiske principper.

Men der var også en bølge af nationalbevidsthed, som bar grundlæggelsen af de nye museer. Også den havde sin rod i Oplysningstiden. Det var f.eks. den franske filosof Montesquieu (1688-1755), der havde hævdet, at den nordiske oldtid med sine guder og helte var et modstykke til den mægtige romerske slavestat, som datidens enevoldsherskere havde som deres forbillede. Norden kom på den måde til at repræsentere frihed over for Sydens ufrihed. Det er en tankegang, som endnu i vore dage lever et solidt efterliv i debatten om et forenet Europa.

\section{ET GULDALDERMUSEUM}

Men først og fremmest var de mange nye museumsgrundlæggelser i 1800-tallets begyndelse forbundet med den nye borgerlige ideologis fremskridtstro og dannelsesideal - og dens krav om offentlighed, bl.a. til offentlige forsamlings- og uddannelsessteder. Det var på den baggrund, at den 29årige, velhavende handelsmand Christian Jürgensen Thomsen (1788-1865) i 1817 overtog den daglige ledelse af de kun 10 år gamle, men allerede støvede samlinger på Trinitatis kirkeloft i København. På ægte købmandsvis bruger han de første år til at rydde op i økonomien og bringe orden $\mathrm{i}$ samlingerne. I 1819 kan han så åbne dørene for det københavnske publikum. Men da er der også i mellemtiden indtrådt et tidehverv: Den danske guldalder er begyndt, og Thomsen bliver i de følgende årtier en mand, der på ejendommelig vis genspejler netop den tids tankegang.
Thomsen var hverken digter eller filosof. Han udtrykte sig ikke gerne på tryk. Det var museumssamlingerne, der var hans udtryksmiddel. Der er dem, der i hans arbejde har set en spækhøkers lyst til at bringe orden i varelageret: Stenølsser for sig, bronzeredskaber for sig, alt i hver sin skuffe. Intet kan være mere forkert. Thomsen færdedes livet igennem i den kreds af mænd, som var toneangivende i guldalderens København, og som omkring 1814 havde konsolideret deres position i offentligheden ved at besætte en række vigtige embeder. Det var den generation, som samlede sig omkring brødrene Ørsted, ${ }^{6}$ og som med deres kulturoptimisme og udviklingssyn skabte en kritisk, empirisk metode og en helhedstænkning, der omfattede både naturvidenskab og humaniora, kunst og religion i en samlet verdensfortolkning. Det frembragte en række dybe indsigter, der slet ikke passer ind i det billede af guldalderen som et kulturelt brakvand, som vi ofte har i dag.

Igennem 1820rne arbejdede Thomsen ihærdigt med sine samlinger, gjorde dem tilgængelige for publikum og opnåede stor succes derved. At besøge hans samlinger ved Rundetårn blev et "must" for de rejsende, der kom til byen, og de begejstredes alle for hans ligefremme museumspædagogik. Men han udviklede sig også samtidig som videnskabsmand og kunstkender og skabte efterhånden i sine samlinger et helhedssyn, der var et fornemt udtryk for guldalderens udviklingstænkning.

Omkring 1830 er Thomsen modnet som videnskabsmand, og igennem de næste to årtier følger hans banebrydende videnskabelige indsats, som finder sted samtidig med, at han făr dyb indflydelse på, og $\mathrm{i}$ mange tilfælde overtager ledelsen af de 
JøRGEN JENSEN

20 kunst- og kulturhistoriske samlinger i København. Han bliver i 1830 udpeget til den kommission, som skal gennemgå og ordne Det kongelige particuliære Rustkammer. Det blev indledningen til et engagement for våbensamlingen, det senere Tøjhusmuseum, som varede livet ud. Så bliver han sammen med to andre kunstkyndige Just Mathias Thiele (1795-1874) og Chr. Fr. von Rumohr (1785-1843) medlem af den kommission, der skal ordne Den kongelige Kobberstiksamling - han ejer selv Københavns største privatsamling af grafiske blade. Han skriver sit responsum for kommissionen, og på det grundlag bliver samlingen udskilt fra det Kongelige Bibliotek og oprettet som en selvstændig samling: "Den kongelige KobberstikStentryk og Håndtegnings Samling”. Så søger han lederstillingen på Den kgl. Mønt- og Medaillesamling, men her bliver han overhalet af den fra England hjemvendte klassiske arkæolog og filolog, P.O.Brøndsted (1780-1842), der velfortjent får direktørstillingen. Thomsen udnævnes i stedet som inspektør, men i 1842 efter Brøndsteds død, overtager han ledelsen af samlingen. I 1832 bliver han også indsat $\mathrm{i}$ den kommission, der skulle gøre Rosenborg til et familiemuseum for den danske kongeslægt, den oldenborgske stamme - han virkede i kommissionen frem til 1844 .

I 1832 bliver han også den reelle leder af Museet for de nordiske Oldsager, som det år blev opsagt fra Universitetet på Trinitatis kirkeloft, ironisk nok af den danske nationaldigter, professor Adam Oehlenschlæger (1779-1850), som dermed viste, at han stadig stod ved, hvad han havde skrevet i sit digt "Guldhornene", at uden for historiens guddommelige sand- hed stod de "mat nysgerrige", samlerne, kort sagt Oldgranskerne og med dem også hele "Publicum fra Byen, Landet, Udlandet inklusive Haandværkssvende og Skoleelever", som der stod i opsigelsesbrevet. Thomsen flytter nu til Christiansborg slot og indretter sit museum i nordfløjen ud mod Ridebanen. Så kommer i 1839 udnævnelsen til leder af Kunstmuseet og Det kgl. Billedgalleri på Christiansborg, som han sammen med kunsthistorikeren Høyen reorganiserer fuldstændigt efter de nyeste kunsthistoriske teorier.

Kunstmuseet, som var det gamle kongelige kunstkammer, reorganiserer han også og slår oldtids- og middelaldersamlingerne sammen med museet på Christiansborg. Ud af de gamle samlinger opretter han Det etnografiske Museum og Antik Cabinettet og begynder derefter af resterne at opbyggge et museum for "Skulptur og Kunstflid", det eneste af Thomsens museer, som ikke eksisterer i dag. ${ }^{7}$

\section{DE FØRSTE MUSEUMSTEMPLER}

Hele denne udvikling og omorganisering af de københavnske museer kan kun forstås, hvis den ses på baggrund af, hvad der samtidig skete i Europa. I Frankrig havde både Lenoirs museum og Musée Napoleon kun fået en kort levetid. Efter Wienerkongressen i 1815 måtte mange af de kunstskatte, der var erobret under Napoleon og anbragt i Louvre leveres tilbage til oprindelseslandet, og snart blev også Lenoirs museum lukket. Det blev sejrherrerne fra Waterloo, der kom til at føre revolutionstidens museumstanker ud i livet. Fra 1820rne og et par årtier frem rejser der sig i talrige europæiske byer en ny type monumentalbygninger, museumstem- 
Christian JÜRgensen Thomsens MUSEUm - EN GULdaldersvision

Christian Jürgensen Thomsen, malet som 60-årig af J.V. Gertner i 1848. Nationalmuseet.

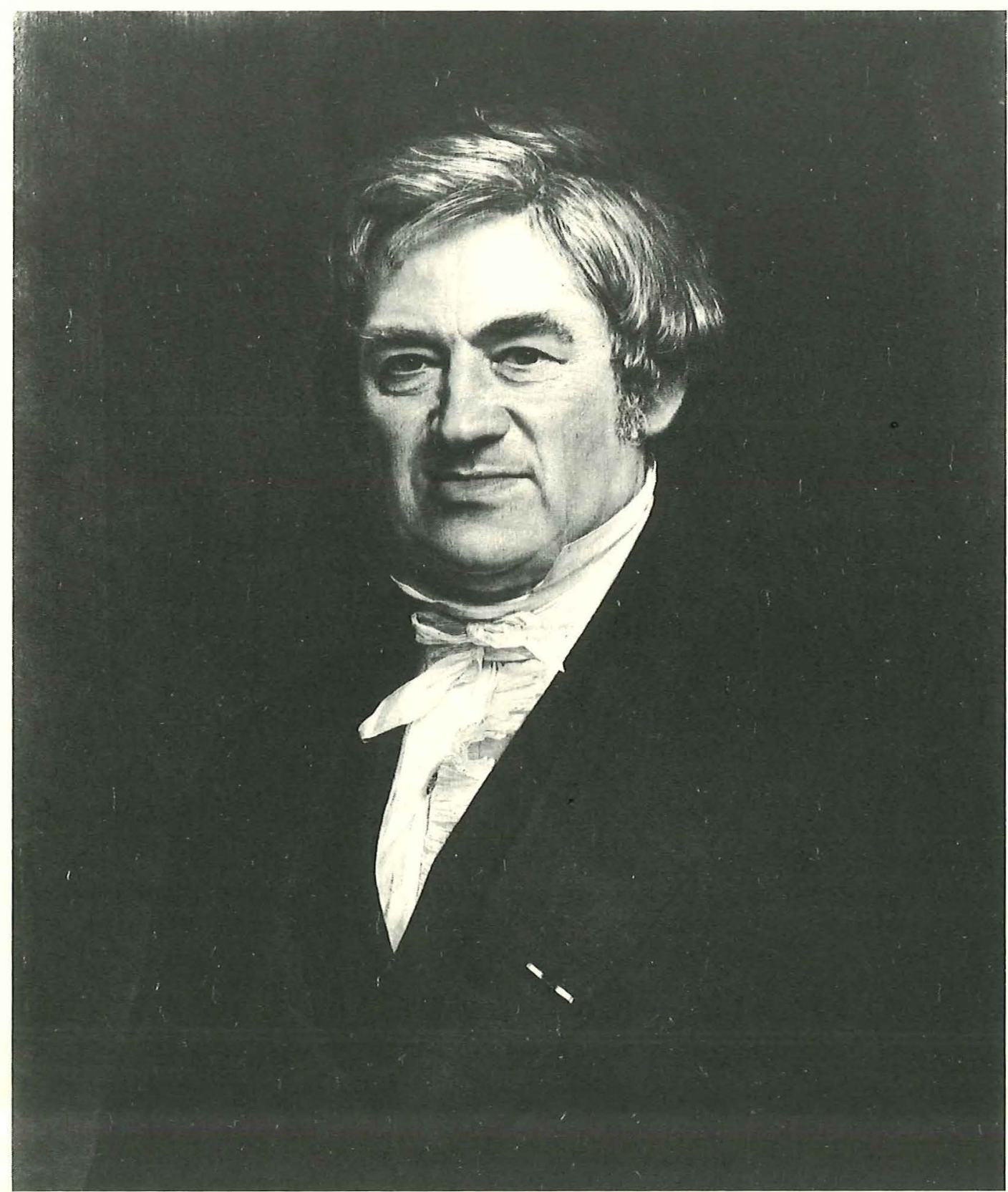


JøRGEN JENSEN

22 pler, bygget $\mathrm{i}$ en romantisk historicerende stil, oftest med græske og romerske forbilleder.

I Georg IV's London begyndte i 1824 byggeriet af det nye British Museum, der med sin storslåede indgang skulle lede tanken hen på Perikles' Athen. ${ }^{8}$ Samme år lagdes grundstenen til Manchester City Gallery, som bliver forbilledet for mange mellemstore neoklassicistiske museer i England. ${ }^{9}$ Manchester var jo en af industrialismens første storbyer. I Edinburgh, også en af de første store industribyer, opføres i 1822-26 The Royal Institution, ${ }^{10}$ og fra 1837 rejser der sig i London på nordsiden af Trafalgar Square, tæt ved imperiets midtpunkt, National Gallery. ${ }^{11}$ Inden for det næste årti opføres i universitetsbyerne Oxford og Cambridge Fitzwilliam Museum og Ashmolean Museum, alle i den samme klassisk inspirerede byggestil. ${ }^{12}$

Det britiske museumsbyggeri havde sit modstykke på kontinentet i Friedrich Wilhelm III's Berlin og Ludwig I's München. I 1830 stod både Friedrich Schinkels Altes Museum og Leo von Klenzes herlige Glyptotek færdigbyggede. Schinkels museum på Museumsinsel i Berlin blev forbilledet for talrige senere museumsbyggerier. ${ }^{13}$ Dets indretning var karakteristisk for tidens kunstopfattelse. Det rummede ingen ikke-europæisk kunst, heller ingen moderne kunst. I stueetagen stod de klassiske skulpturer, som ikke var kronologisk opstillede men fremstod som en historisk helhed. Malerierne i den øvre etage var derimod opdelt efter perioder og skoler. Den klassiske kunst var endnu tidløs og fundamental. Den nyere tids kunst var historisk og foranderlig.

Karakteristisk var også museets placering sammen med kongeslottet og domkirken.
Schinkel ønskede at anskueliggøre den ideelle enhed af kongemagt, kirke og museum, som var så basal $\mathrm{i}$ den preussiske stat. Ud mod den åbne Lustgarten, der lå mellem museet og kongeslottet, og hvor borgerskabet kunne promenere, åbnede Altes Museum sig med sin søjlerække lig en græsk stoa. Det var Schinkels idé, at den foran liggende plads skulle opleves som en atheniensisk agora, midtpunktet i de græske borgeres liv. Men gik man gennem indgangen til museet, blev dets tempelkarakter straks klar: Man trådte ind i en rotunde, der ledte tanken hen på det romerske Pantheon, og som hos den besøgende skulle skabe den rette andægtighed før mødet med den ophøjede kunst.

I Ludwig I's München kunne man se den samme forening af det sakrale og det profane i Leo von Klenzes storslåede Glyptotek ved Königsplatz. ${ }^{14}$ Det var både en privatsamling og en offentlig samling og stod som en central bestanddel i det Nordens Athen, som den bayerske konge stræbte efter at skabe i sin residensstad. I sin plan greb Königsplatz og de omgivende bygninger tilbage til Forum Romanum, selv om byggestilen var græsk. Hensigten var at indpasse museet $\mathrm{i}$ den treklang af kunst, religion og historie, som pladsens samlede arkitektur var udtryk for.

\section{THOMSENS MUSEUM}

I København rejstes ikke noget museumstempel - ikke før Thorvaldsens Museum. Men her tænktes alligevel de samme tanker som i Berlin, München og London. I 1838 fremkom arkitekten Hetsch f.eks. med et forslag til et dansk Nationalmuseum, der skulle bygges, hvor Marmorkirken ligger i dag. ${ }^{15}$ Med sin centrale rotunde og sin søj- 
lerække ledte det tanken hen på de samtidige europæiske museumsbygninger, først og fremmest Schinkels Altes Museum i Berlin. Men til et Nationalmuseum blev det ikke i den omgang, selv om et sådant var ved at vokse frem under Thomsens hænder. Det var imidlertid ikke bygningen men indholdet, der var det væsentlige for ham. Og netop her omkring 1840 står han på højdepunktet af sin skabergerning. Han er da ved at opbygge sit Etnografiske Museum, et af de første i verden.

1830rne og 1840rne var en periode, hvor Danmark udenrigspolitisk og økonomisk åbnede sig mod verden. Adskillige marinetogter går i de år til oversøiske lande, bl.a. for at afvikle de gamle kolonier og med det formål at etablere handelstraktater. $\mathrm{Og}$ Thomsen griber lejligheden. Han giver instrukser til besætningerne om indsamling af etnografica, og han får ad samme vej kontakter til adskillige danske i fjerne lande, P.W. Lund i Brasilien ${ }^{16}$ og Mads Lange på Bali, ${ }^{17}$ for blot at nævne nogle, og får dem til at bidrage til indsamlingen. $\mathrm{Og}$ han støttes deri af Det kgl. nordiske Oldskriftselskab, som havde et omfattende net af kontakter til akademikere, embedsmænd og standspersoner over hele verden. Han inddrager også missionærerne på Grønland i sit virke - og han rejser selv til Frankrig, Holland og England, typisk nok de liberale handelsnationer med oversøiske kontakter, for at træffe berømte etnografer som Philipp Franz von Siebold (17961866) i Leiden og Edmé Francois Jomard (1777-1862) i Paris for at lære af deres idéer om etnografiske museer. ${ }^{18}$

Det er med inspiration herfra han skaber et omfattende kulturhistorisk udviklingssystem, en sammenlignende kulturhistorie, som han anskueliggør i sine udstillinger.
Her lader han alverdens folkeslag, "nationer", som han kalder dem, skride frem gennem en række stadier, fra en "Vildheds Tilstand" over en begyndende beherskelse af smedekunsten og brugen af metaller til anvendelsen af skrift og skabelsen af en selvstændig litteratur. Og for hvert stadie redegør han for, hvordan klimaet i de kolde, de tempererede og de varme zoner spiller ind og modificerer de grundlæggende træk i kulturen. Hele tiden understreger han "hvormeget selv fjerne Nationer ligner hverandre i de Redskaber og Midler de bruge, når de ståe på samme Grad af Kultur" - og hvorledes "vi saaledes af det Nuværende kunne slutte os til meget om Fortiden". De museumsbesøgende på Thomsens Etnografiske Museum skulle så at sige kunne se sig selv $\mathrm{i}$ datid $\mathrm{i}$ hans udstillinger.

I de samme år tager han fat på de nationale samlinger fra oldtiden og middelalderen på Christiansborg slot. ${ }^{19}$ Dem udvider han ved at slå Oldsagskommissionens og det gamle Kunstkammers samlinger sammen. Her bygger han videre på sit treperiodesystem, som han havde udviklet allerede i 1820rne, og uddyber billedet af hovedepokerne stenalder, bronzealder og jernalder. Samtidig bruger han den viden, som han under sine rejser i 1840'rne har indsamlet om de europæiske landes ældste historie, til at give et billede af kontinentets generelle kulturudvikling, hvor han får sat den græske, den etruskiske, den romerske og den keltiske kultur i et korrekt tidsmæssigt og geografisk forhold til hinanden. Bl.a. er han i stand til at jævnføre den nordeuropæiske bronzealder med den græske. Han indleder også et samarbejde med den dengang fremherskende comparative anatomi, som herhjemme repræsente- 
24 redes af professor Daniel Eschricht (17981863), om et studium af de menneskeracer, som bar udviklingen i de forskellige områder.

Endelig tager han fat på AntikCabinettet med dets samling af middelhavslandenes oldsager, hvis vigtighed han betoner, idet han siger, at de "jo egentlig leverer os Kendsgerningerne for Menneskeaandens Udvikling fra dens første Barndom indtil den havde naaet den største Modenhed", idet det "var den samme Aand med de samme medfødte Evner, der uvikledes, det var de samme naturlige Tilbøjeligheder og tildels de samme Hovedfornødenheder, der paavirkede Udviklingen, om end Forskellighed og klimatiske og lokale Forhold modificerede dem på en mere individuel, forskellig Maade" - et forbløffende uimponeret syn på middelhavslandenes oldtid $i$ en periode, hvor begejstringen for det klassiske triumferede som aldrig før. Men han opstiller altså også middelhavslandenes oldsager $\mathrm{i}$ overensstemmelse med sit udviklingssyn, noget ganske uhørt i samtiden.

\section{GULDALDERENS HELHEDSSYN}

Sådan får Thomsen anskueliggjort sin sammenlignende udviklingsteori, sin altomfattende, historiske verdensfortolkning, og sin dybe overbevisning om, at hele menneskeheden er én. Det var en tanke, som var et ægte barn af den danske guldalders idélære. Lige som sin samtidige, H.C.Ørsted, der i disse år skrev om "Aanden i Naturen", skaber Thomsen et nyt syn på menneskehedens historie og tegner billedet af en udvikling, der var begyndt med det ringere og ufuldkomnere og langsomt havde hævet sig opefter.
Sideløbende med at denne opfattelse udvikler sig, foregår der overalt i Europa en stigende videnskabeliggørelse af historiesynet. I kunsthistorien f.eks. begyndte den kildekritiske metode at udvikles. Det skete bl.a. i C.F. von Rumohrs skrift "Italienische Forschungen" fra 1826, der adskilte den idealistiske kunstæstetik fra kunstens udviklingshistorie og lagde grunden til den egentlige kunsthistoriske forskning. Thomsen kendte von Rumohr fra sit arbejde med Kobberstiksamlingen, og han modtog, ligesom vennen og kollegaen N.L. Høyen (1798-1870), stærke påvirkninger fra von Rumohr. Det kom til udtryk, da de to mænd i 1839 foretog nyophængningen af malerierne i Det kongelige Billedgalleri på Christiansborg. Her var det dog Høyen, der var den ledende i arbejdet.

Sin egen og helt selvstændige indsats ydede Thomsen derimod med den videnskabelige systematik, han udviklede i de kulturhistoriske samlinger - med sin opdeling af oldtiden $i$ en stenalder, en bronzealder og en jernalder. Disse begreber kom til at betyde det samme for tidsopfattelsen, som artsbegrebet havde gjort for naturopfattelsen. De var begyndelsen til en systematisk periodisering af historien og var med til at lægge grunden til den arkæologiske forskning, som åbnede for et årtusindlangt perspektiv i menneskets historie forud for de skrevne kilder. Denne nye historiske erkendelse gik hånd $\mathrm{i}$ hånd med bl.a. geologen Charles Lyells (1797-1875) forkastelse af de katastrofeteorier, som hidtil havde været en accepteret forklaring på jordklodens og menneskehedens tilblivelseshistorie. I samme retning gik også de iagttagelser, som den unge forsker Charles Darwin (1809-1882) i 1830rne gjorde på sin jordomsejling. Tilsammen førte det 
Arkitekten G.F. Hetsch's aldrig udforte prosjekt til et Pantheon og Nationalmuseum $i$ Kobenhavn fra 1837. Kunstakademiet.

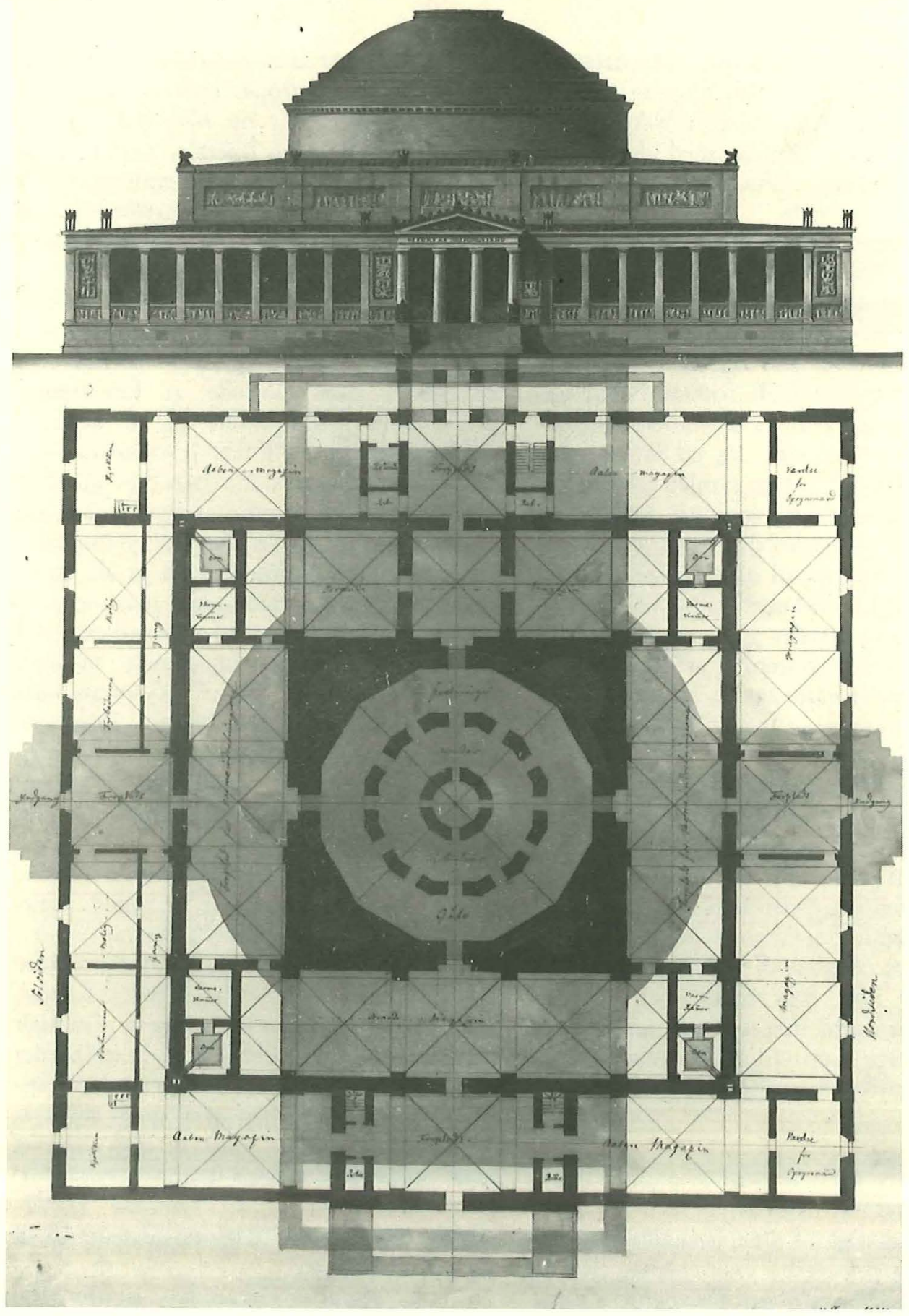


26 stilfærdige samarbejde mellem alle datidens forskere om at udrede udviklingens enkeltheder langsomt frem til et udviklingssyn, der lod verden begynde med det enkle, usammensatte og derfra hæve sig til mere komplicerede former.

I guldalderens København, denne ejendommelige lilleby med det store udsyn, fik disse tanker deres særegne form. Man har kaldt det organismetænkningen, den kritiske romantik eller slet og ret den danske idélære. Den betegnede romantikkens udvidelse af klassicismens idéverden. Fornuften var blevet til sjæl, og ud af den forvandling var opstået en samlet verdensfortolkning, som omfattede kunst, religion og videnskab. Hver af disse tre elementer angav en mulig vej til den højeste indsigt $\mathrm{i}$ tilværelsen: Videnskaben ledte til det sande, religionen til det gode og kunsten til det skønne. I sin forening af disse tre elementer var det naturligt, at museet kom til at stå som noget centralt i det borgerlige dannelsessystem.

Denne helhedstænkning, som navnlig var fremherskende i Centraleuropa og Norden, havde historien som et af sine centralbegreber. Sådan kom det til udtryk i H.C. Ørsteds skrifter, hvor han fandt, at hver enkelt levende organisme rummer, forstået som proces, nøglen til verdensgådens løsning. Og ikke blot mennesker, dyr og planter, men også den samlede natur og de menneskelige samfund forstås som individer og fortolkes historisk som livsløb.

\section{NYE TIDER}

Dette fornemme helhedssyn, som Thomsen lige som mange af sine jævnaldrende var bærer af, gennemgik i enevældens sidste år nogle radikale ændringer. Igennem 1830rne og 1840rne var den politiske temperatur steget overalt i Europa. Den nationalpolitiske bevægelse, der nu blev båret af en generation af yngre liberale, formulerede deres krav langt mere vidtgående end den ældre generation - som til gengæld mistede sin centrale position i offentligheden. For den yngre generation var kunsten og historien et medium for folkeoplysning. Thomsens 10 år yngre ven, kunsthistorikeren Høyen, sluttede sig f.eks. til den nye bevægelse, som krævede at kunstnerne skulle være folkeoplysere og at kunsten skulle formidles til "folket" i nationale værker. Udbredelsen af dannelsen blev nu til et forhold mellem en elite af formyndere og en modtagende masse. Det tidlige industrisamfunds massekultur er ved at slå igennem. I museernes verden kan man også se, hvordan de nye tanker kommer til udtryk i dannelsen af de nye nationale museer: Musée Cluny i Paris, ${ }^{20}$ Germanisches Nationalmuseum i Nürnberg, ${ }^{21}$ RömischGermanisches Zentralmuseum i Mainz ${ }^{22}$ osv., som i hele deres form afviger fuldstændigt fra museumstemplerne fra 1820rne og 1830rne.

Over for dette nye syn på kulturformidlingen stod Thomsen helt fremmed. Hans samfundsyn var i egentligste forstand patriarkalsk og faldt helt i tråd med det kendte landsfaderlige i den dansk-tyske helstat. Han forstod sig ikke på det nye, nationalt orienterede samfund bestående af indbyrdes konkurrerende grupper, der var under fremvækst. Og selv om han af al magt søger at undgå konflikterne, viser de sig alligevel med tydelighed $\mathrm{i}$ hans komplicerede forhold til eleven J.J.A. Worsaae (18211885), der netop i 1840rne støttede sig til de nationalliberale.

I 1849 afskaffes enevælden, og den frie 
Christian JÜRgEnSEN ThOMSENS MUSEUM - EN GULdALdERSision

forfatning indføres. Thomsen bliver nu stillet over for kravet om at flytte hovedparten af sine samlinger til én bygning, Prinsens Palæ. Alt skal samles under ét tag. Og han foretager nu den sidste store kraftudladning: I løbet af få år, frem til 1855 gennemfører han flytningen og stiller samlingerne op, den etnografiske samling, Antik cabinettet og oldsagssamlingen, så de samlet belyser den vision, han havde om menneskehedens udvikling og om, at de menneskelige kulturer overalt $i$ verden er én. Folkestyret havde modtaget en fornem arv fra den danske guldalder.
FOLKESTYRET OG MUSEET

Hvordan modtog det unge folkestyre så denne arv? Ja, her må man konstatere, at enevældens ophør og folkestyrets indførelse straks betød en kraftig nedgang $\mathrm{i}$ det offentliges støtte til kunsten og videnskaben. ${ }^{23}$ Nedskæringerne skete, uden at der i Rigsdagen blev givet nogen virkelig motivering herfor. Men baggrunden var sikkert, at det nyoprettede kultusministerium under filologen J.N. Madvigs (1804-86) ledelse havde den opfattelse, at det ville være klogt at gå forsigtigt frem over for den på sparsommelighed indstillede Rigsdag.

Prinsens Pale, som det så ud, efter at C.J Thomsen $i$ 1850erne havde flyttet sine samlinger dertil. Tegning af H.G.F. Holm 1857, Nationalmuseet.

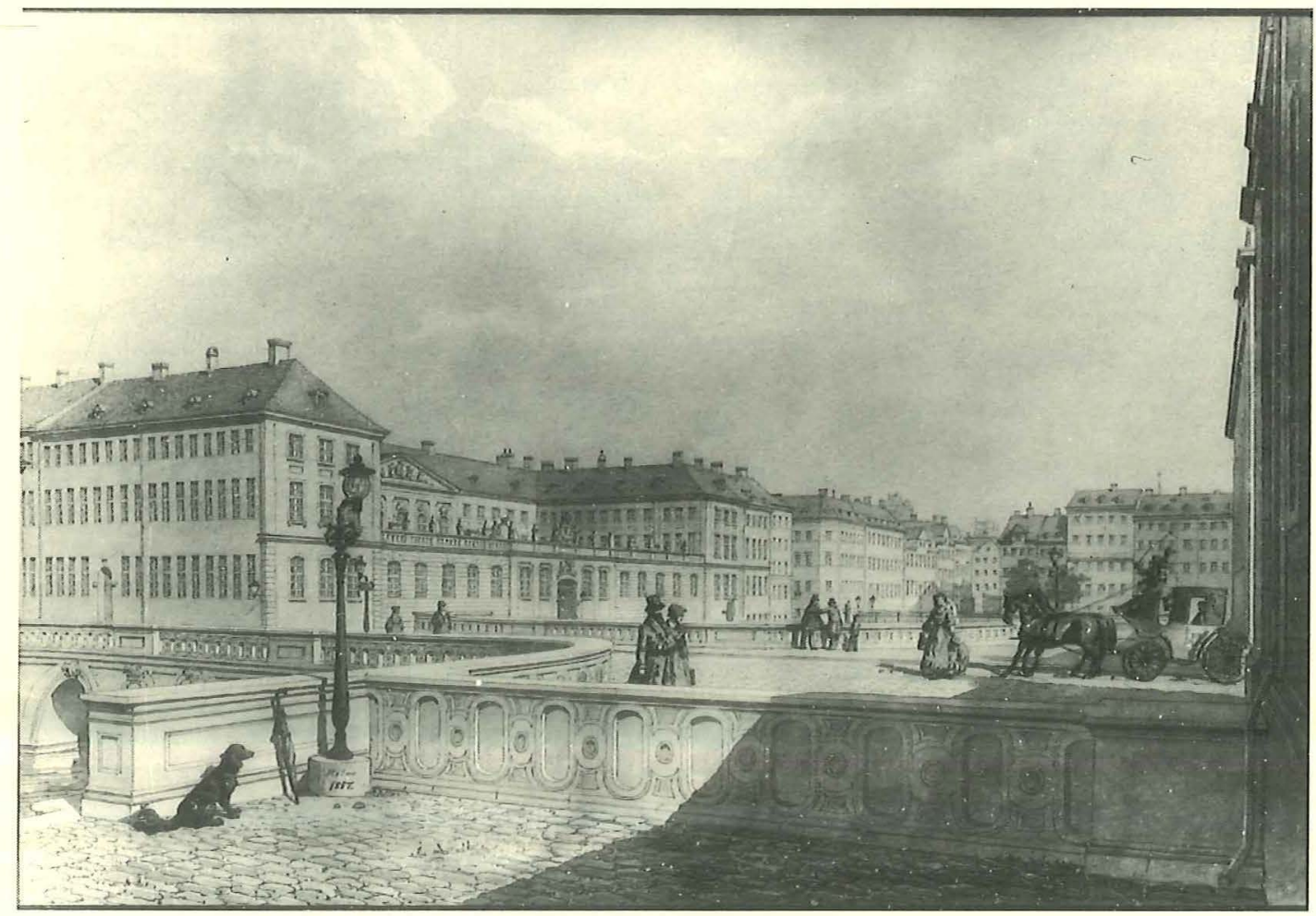


JøRGEN JENSEN

28 Før 1849 kunne menigmand vanskeligt give udtryk for, at han anså majestætens dispositioner for ødsle, selv om mange uden tvivl har ment det. Efter grundlovens indførelse får man en offentlig debat, og her må man konstatere, at Parkinson havde ret, når han sagde, at det ofte er de mindste bevillinger, der giver anledning til den største diskussion, fordi de angår formål, enhver kan forså, og summer hvis størrelse alle kan fatte.

Helt fortvivlende var museernes stilling dog ikke. At det var tilfældet, skyldtes alene Thomsen, som allerede fra december 1848 gennem et meget vanskeligt kommissionsarbejde havde fået ordnet museernes forhold under det nye styre. Kommissionen skulle fordele de økonomiske forpligtelser mellem staten på den ene side og kongen på den anden. Det lykkes Thomsen at fă gennemført nogle rimelige budgetter og i visse tilfælde også at få dem hævet $\mathrm{i}$ forhold til tidligere bevillinger. Men at det lykkedes, skyldtes alene den høje anseelse han nød blandt de nationalliberale politikere, der jo for en stor del var akademikere.

Thomsens museum var en arv fra enevælden, og så folkeligt det end var, blev det dog betragtet med mistænksomhed af de grupper, der udgjorde den venstre del af Rigsdagen. Der var mange nationalliberale politikere, der i disse år med stigende forskrækkelse konfronteredes med venstrefolkenes, bondevennernes, utilslørede klassepolitik. Selv om denne udsprang af en nok så retfærdig social indignation, virkede den alligevel ofte smålig og provinsiel, ikke mindst i kulturelle spørgsmål.

Allerede i 1855 kommer der fra venstre side af salen forslag om at nedsætte bevillingen til Det etnografiske Museum.
Begrundelsen var, at museet nu var så vel udstyret, at det måtte være nok. Yderligere indkøb behøvedes ikke. "Hvad Nytte har vi af Forbindelser med fremmede Verdensdele som Kina og andre Steder, hvormed vi ellers intet har at gøre", spurgte man.

Her er det nationalliberale politikere som Hall, H.N. Clausen, Orla Lehmann og D.G. Monrad, der forsvarer museerne. $\mathrm{Og}$ de gør det ved at henvise til, at Thomsen har skaffet landet samlinger, som i andre lande koster ganske anderledes summer at tilvejebringe.

Men det stopper ikke venstrefolkenes angreb. I de følgende år kommer der fortsatte forslag om nedskæringer, og den som bliver Thomsens hårdeste modstander, er krigsministeren fra krigen mod holstenerne i 1848, nu formand for finansudvalget, A.F. Tscherning (1795-1874). Han er i 1860 bl.a. ude efter skulptursamlingens og det etnografiske museums bevillinger, og siger, at Thomsen har pådraget landet en masse samlinger, som langt går ud over det forstandige behov. ${ }^{24}$ Han siger videre, at Thomsen har erobret det ene palæ efter det andet til sine samlinger - ja, at det nu optager næsten alle huse i København, og københavnerne skulle også have huse at bo $\mathrm{i}$.

Tscherning slutter sit indlæg med at sige "Det er en fuldkommen fejlagtig Betragtningsmaade at Danmark, et $\mathrm{i}$ og for sig lille Land, paa denne Maade skal træde i Spidsen for Videnskaber og Kunst og kappes med alle andre Folkeslag i denne Henseende, medens vi i mange langt vigtigere Retninger bliver staaende tilbage". Han anfører endvidere, at alt hvad der hører under kultusministeriet indtager en ganske urigtig plads herhjemme ... og hindrer en naturligere udvikling af hele livet og af virkelig oplysning. Tscherning vidste 
nok, at han med disse udtalelser ville støde an mod den herskende klasse. Men, sagde han, "Sandheden vil engang komme til sin ret." $\mathrm{Nu}$ f. eks. alle disse både fra Grønland. "Mon ikke der kommer en Dag, hvor vi roligt kan se på, om vi har en Baad mere eller mindre fra Grønland". Tscherning slutter med fyndigt at sige: "Det er ikke Kajakker vi lever af". Endnu hundrede år senere kunne man høre de samme toner i det danske folketing. Det var i 1950erne, da finansudvalgsformanden Jensen Broby talte om "indianderragelset" på Nationalmuseet.

Men museet stod der - takket være Thomsen - og det blev trods alt stående. Men Thomsens fornemme helhedssyn, hans guldaldervision, afvikledes efterhånden. Det blev gjort af en forskning, der havde den positivistiske empiri som det eneste videnskabelighedskriterium. Men mon ikke museet i dag kunne have behov for at søge tilbage til den fortrængte helhedstænkning, som knytter de humanistiske fag sammen. Hvis vi da har ønsket om at være andet end historisk underholdning. Det er her, Thomsens vision kan bruges, ikke som en gentagelse men som en endnu levende inspiration.

\section{SUMMARY}

\section{Christian Jürgensen Thomsen's Museum - a Vision of the Golden Age}

The foundation of the National Museum in Copenhagen in 1807 was a late result of the Danish cultural policy at the end of the Enlightenment period. The inspiration came from France, primarily from Alexandre Lenoir's Musée des Monuments Français established in 1793 and from the Musée Napoleon opened in 1804 in the Louvre, both of them didactically arranged art collections open to the public. A major step in the development of the Danish National prosperous businessman, Christian Jürgensen Thomsen (1788-1865), took over the management of the collections on a full-time basis. In 1819 he was also able to open the doors of the museum and admit the public to the new didactic arrangement of the collections. Thomsen knew how to attract the general public with his lively guided tours. But he was also a brilliant scholar. Through systematic study of the ancient artefacts which were delivered to the museum, he arrived at the conviction, as early as the 1820 s and before anyone else in Europe, that prehistory could be divided up into a Stone Age, a Bronze Age and an Iron Age.

Thomsen's work took place during the first half of the 19th century, a period which in Denmark has later been called the Golden Age. Culturally it was a very rich period which also saw the reorganisation of the many museum collections in Copenhagen - and Thomsen became the director of most of them. He had a thorough knowledge of European museum development at that time, of the contemporary museums in Britain and on the Continent: the British Museum in London, the Altes Museum in Berlin and the Glyptotek in Munich, all of them built in the neo-classical style so characteristic of the bourgeois culture. In contrast to other European cities Copenhagen did not see the erection of any neo-classical museum temple. However, at the end of the 1840's most of Thomsen's collections were moved to the 'Prinsens Palæ' (the Crown Prince's Palace), a beautiful 18th century rococo palace in the heart of Copenhagen

where they are still housed. Here he created a universal museum comprising an ethnographical collection, a coin collection side by side with prehistoric and historical collections.

Thomsen's museum concept was typical of the evolutionism of the Golden Age. His arrangement of the collections reflected his own evolutionary ideas which saw mankind developing trough identical evolutionary stages throughout the world. His museum became immensely popular with the public and acquired a repu- 
JøRGEN JENSEN

30 tation which reached far beyond Denmark's borders.

In 1849 Denmark gained a new constitution and Thomsen's museum became state property. Making an impressive effort the now 60-year-old Thomsen adjusted his museum to the new political situation even if, paradoxically, he was met with a certain scepticism by the politicians. The left wing politicians of the new parliament especially wanted to cut his budgets. But thanks to Thomsen's organisational talents his museum survived and still exists as an impressive manifestation of the holistic thinking of the Golden Age.

Jorgen Jensen, mag.art i forhistorisk arkeologi, museumsinspektor på Nationalmuseet, afdelingen for oldtid og middelalder. Har i 1992 udgivet "Thomsens Museum. Historien om Nationalmuseet". Hans øvrige litterere produktion omfatter bl.a. flere oversiktsverker om dansk oldtidshistorie (Adr: Nationalmuseet, OMA. Frederiksholms Kanal 12, DK-1220 Kobenhavn K).

\section{NOTER}

1. Jørgen Jensen: Thomsens Museum. Historien om Nationalmuseet. København 1992.

2. A. Erlande-Brandenburg: Le Musée des Monuments francais et les origines du Musée Cluny. I: B. Deneke og R. Kahsnitz (red.): Das kunst- und kulturgeschichtliche Museum im 19. Jabrhundert. Studien zur Kunst des neunzehnten Jahrhunderts 39. München 1977.

3. Majorie Caygill: The Story of the British Museum. London 1981.

4. Aufklärung und Klassizismus in Hessen-Kassel unter Landgraf Friedrich II. 1760-1784. Udstillingskatalog Kassel 1979.

5. P. Wescher: Kunstraub unter Napoleon. Berlin 1976.

6. H.C. Ørsted (1772-1851), fysiker og ledende skik kelse i dansk naturvidenskab. A.S. Ørsted (17781860), jurist og indflydelsesrig embedsmand.

7. Jørgen Street-Jensen: Christian Jürgensen Thomsen und Ludwig Lindenschmit: Eine Gelehrtenkorrespondenz aus der Frübzeit der Altertumskunde (18531864). Römisch Germanische Zentralmuseum.
Monographien Band 6, Mainz 1985, s. $10 \mathrm{ff}$.

8. Majorie Caygill: op.cit.

9. H.G.Archer: Art and Architecture in Victorian Manchester. 1987.

10.Esme Gordon: The Royal Scottish Academy. Edinburgh 1976.

11.Philip Hendy: The National Gallery of London. London 1960.

12.G. Waterfield (red.): Palaces of Art. Art Galleries in Britain 1790-1990. London 1991, s. $149 \mathrm{ff}$ og $153 \mathrm{ff}$.

13. Renate Petras: Die Bauten der Berliner Museums Insel. Berlin 1987.

14.Klaus Vierneisel og Gottlieb Leinz (red.): Glyptothek München 1830-1980. Jubiläumsausstellung zur Entstehungs- und Baugeschichte, 17. September bis 23. November 1980. München 1980.

15.Kjeld von Folsach: Fra nyklassicisme til historicisme. Arkitekten G.F.Hetsch. København 1988.

16.Tove Hatting: Peter Wilhelm Lund. Naturens Verden 1980, s. 179-196.

17.Inger Wulff: Mads Langes Gaver fra Bali. Nationalmuseets Arbejdsmark 1954, s. 83-94. - Paul Andresen: Mads Lange fra Bali og hans efter slagt, sultanerne af Johor. Odense 1992.

18.Jørgen Jensen: op.cit., s. $198 \mathrm{ff}$.

19.Jørgen Jensen: op.cit., s. $261 \mathrm{ff}$.

20.A. Erlande-Brandenburg: op.cit.

21.Ingolf Bauer: König Maximilian II,sein Volk und die Gründung des Bayrischen Nationalmuseums. Bayrisches Jahrbuch fir Volkskunde 1988, s. 1-38. Hubert Glaser: "...ein Bayrisch historisches Museum im weitesten Sinne des Wortes...”. I: Marie-Louise von Plessen (red.): Die Nation und ihre Museen. Frankfurt/Main 1992, s. 271-280.

22.Gero von Merhardt: Das Römisch-Germanische Nationalmuseum, Rückblick und Ausblick. Festschrift RGZM. 1952, s. 194-200.

23.Aage Rasch: Staten og kunstnerne. Bevillinger og meninger under enevælde og folkestyre. Skrifter udgivet af Jysk Selskab for Historie 22. Aarhus 1968.

24.Jørgen Jensen: op.cit. s. 370 ff. Festschrift RGZM. 1952, s. 194-200. 